\title{
AKTIVITAS ANTIBAKTERI DAN BIOAUTOGRAFI EKSTRAK ETANOL, FRAKSI NON POLAR, SEMIPOLAR SERTA POLAR DAUN SIRSAK (Annona muricata L.) TERHADAP Klebsiella pneumoniae DAN Staphylococcus epidermidis
}

\author{
Haryoto*, Yuliana Dwi Jayanti, Henggar Prasetyo Wikan Saputro, Kosworo \\ Fakultas Farmasi Universitas Muhammadiyah Surakarta Jl. A. Yani Tromol Pos 1, Pabelan Kartasura, \\ Surakarta 57102 \\ *Corresponding author email: haryoto@ums.ac.id
}

\begin{abstract}
Abstrak
Penyakit infeksi masih merupakan penyakit utama dan penyebab kematian tertinggi di Indonesia. Salah satu tanaman yang dapat dimanfaatkan sebagai obat adalah tumbuhan sirsak. Penelitian ini bertujuan untuk mengetahui Kadar Hambat Minimum (KHM) ekstrak etanol, fraksi nonpolar, semipolar dan polar daun sirsak (Annona muricata L.) terhadap Klebsiella pneumoniae dan Staphylococcus epidermidis serta golongan senyawa kimianya yang mempunyai aktivitas antibakteri terhadap Klebsiella pneumoniae dan Staphylococcus epidermidis. Daun sirsak diekstraksi dengan metode maserasi menggunakan etanol 96\%. Uji aktivitas antibakteri dilakukan menggunakan metode dilusi padat. Untuk mengetahui kandungan senyawa dari ekstrak etanol daun sirsak dilakukan uji Kromatografi Lapis Tipis. Bioautografi dilakukan untuk mengetahui kandungan senyawa yang terdapat dalam ekstrak etanol daun sirsak yang berkhasiat sebagai antibakteri yang ditunjukkan dengan adanya zona jernih pada media yang telah diinokulasi bakteri dan ditempeli plat KLT hasil elusi ekstrak etanol daun sirsak. Uji Kromatografi Lapis Tipis menggunakan fase diam silika gel $\mathrm{GF}_{254}$ dan fase gerak heksan:etil asetat (7:3). Hasil penelitian menunjukkan bahwa ekstrak etanol daun sirsak, fraksi nonpolar, semipolar dan polar mempunyai aktivitas antibakteri terhadap Klebsiella pneumoniae dan Staphylococcus epidermidis dengan KHM berturut-turut sebesar 2,5\% 3\%; 3,5\%; 4\% dan $4,5 \%$ b/v. Hasil KLT menunjukkan bahwa golongan senyawa yang terkandung dalam ekstrak etanol daun sirsak adalah polifenol, antron, antranol, triterpenoid saponin, dan steroid saponin. Golongan senyawa dari ekstrak tersebut yang memiliki aktivitas antibakteri terhadap Klebsiella pneumonia adalah senyawa golongan saponin, polifenol, dan antakinon. Sedangkan Golongan senyawa dari ekstrak tersebut yang memiliki aktivitas antibakteri terhadap Staphylococcus epidermidis adalah senyawa golongan polifenol dan antrakinon.
\end{abstract}

Kata kunci : Annona muricata L., antibakteri, Klebsiella pneumoniae, Staphylococcus epidermidis, ekstrak etanol, 3 fraksi dan bioautografi

Accepted on:

DOI: $\underline{\text { https://.doi.org/10.25026/jsk.v1i9.60 }}$

\section{PENDAHULUAN}

Penyakit infeksi masih merupakan penyakit utama dan penyebab kematian tertinggi di Indonesia (Batubara, 2008). Selain itu, muncul pula masalah resistensi antibiotik yang saat ini menjadi perhatian dunia (Westh et al., 2004). Seiring meningkatnya penyakit infeksi dan jumlah bakteri yang resisten, mendorong para ilmuwan untuk menemukan senyawa antibakteri baru yang poten tetapi tidak menjadikan bakteri resisten serta lebih terjangkau dari sisi ekonomi (Hertiani et al.,2003).

Jumlah bakteri di alam yang bersifat patogen sangat banyak. Bakteri yang dapat menyebabkan infeksi tersebut di antaranya Klebsiella pneumoniae dan Staphylococcus epidermidis. Klebsiella pneumoniae memiliki antigen $\mathrm{O}$ dan antigen $\mathrm{K}$ yang keduanya mampu meningkatkan patogenitas. Selain itu, Klebsiella pneumoniae mampu memproduksi enzim ESBL (Extended 
Spectrum Beta Lactamase) yang dapat menyebabkan bakteri kebal dan sulit untuk dilumpuhkan (Danan, 2011; Podschun et al., 1998). Sedangkan Staphylococcus epidermidis

bertanggung jawab atas banyak kasus sepsis pada bayi yang baru lahir (Isaacs, 2003).

Karakteristik Staphylococcus epidermidis adalah memproduksi kapsul atau lendir yang dihasilkan dalam pembentukan biofilm sehingga terlindungi terhadap serangan dari sistem kekebalan tubuh dan antibiotik. Oleh karena itu, infeksi oleh Staphylococcus epidermidis sulit untuk dihentikan (Fitzpatrick, et al., 2005). Penelitian sebelumnya menunjukkan bahwa ekstrak aseton dan etanol daun sirsak (Annona muricata L.) memiliki aktivitas antibakteri terhadap Bacillus subtilis, Eschericia coli, Pseudomonas aeruginosa, Salmonella typhosa, Shigella flexneri, Shigella flexneri $3 a$, Staphylococcus albus, dan Staphylococcus aureus (Taylor, 2002; Prachi et al., 2010).

Selain itu ekstrak air buah sirsak menunjukkan aktivitas antibakteri terhadap Staphylococcus aureus dan Vibrio cholerae (Vieria et al., 2010). Tanaman sirsak memiliki beberapa kandungan senyawa, salah satunya adalah tanin (Prachi et al., 2010). Menurut Akiyama et al.,2001 menyatakan bahwa asam tanin juga dapat digunakan sebagai agen pembantu yang berguna untuk pengobatan infeksi kulit yang disebabkan oleh Staphylococcus aureus selain antibiotik $\beta$-lactam.

Berdasarkan hasil penelitianpenelitian tersebut, menarik bila dilakukan penelitian lebih lanjut untuk mengetahui aktivitas ekstrak etanol daun sirsak terhadap bakteri Klebsiella pneumonia dan Staphylococcus epidermidis.
Penelitian ini dilakukan untuk mengetahui Konsentrasi Hambat Minimum (KHM) pada ekstrak daun sirsak (Annona muricata L.) serta golongan senyawa kimianya yang mempunyai aktivitas antibakteri terhadap Klebsiella pneumoniae dan Staphylococcus epidermidis.

\section{METODOLOGI PENELITIAN}

\section{Alat dan Bahan}

Alat yang digunakan dalam penelitian ini adalah bejana stainless steel, blender, pengaduk kayu, vacum rotary evaporator (Heidolph), penangas air, cawan porselen, neraca analitik (Precisa), mikroskop (Olympus CK21), object glass, deck glass, penjepit, pipet tetes, ose, autoklaf (My life), oven (Memmert) mikropipet (Socorex), Beaker glass, bunsen, blue tips, yellow tips, batang pengaduk, api bunsen, pipa kapiler, Laminar Air Flow (LAF) Cabinet, inkubator (Memmert) chamber, lampu UV $254 \mathrm{~nm}$ dan $366 \mathrm{~nm}$, dan alatalat gelas lainnya (Pyrex).

Bahan yang digunakan adalah daun sirsak yang diperoleh dari daerah Karanganyar, etanol 96\%, K. pneumonia yang diperoleh dari Laboratorium Mikrobiologi Fakultas Kedokteran Universitas Muhammadiyah Surakarta, $S$. epidermidis yang diperoleh dari Laboratorium Mikrobiologi Fakultas Farmasi Universitas Muhammadiyah Surakarta, pelarut (DMSO 100\%), media Mueller Hinton (MH) (Oxoid), media Brain Heart Infusion (BHI) (Conda Pronadisa), standar Mc. Farland (Remel), akuades, akuades steril, alkohol $70 \%$, formalin $1 \%$, cat Gram A, cat Gram B, cat Gram C, cat Gram D, silika gel $\mathrm{GF}_{254}$ (Merck), heksan (p.a. Merck), etil asetat (p.a. Merck), pereaksi semprot yaitu $\mathrm{FeCl}_{3}$, sitroborat, larutan Liebermann Burchard, $\mathrm{KOH}$ etanolik 10\%, kertas 
saring, aseton, media KIA, media LIA, media MIO, dan mediaMSA.

\section{Determinasi tanaman.}

Determinasi simplisia dilakukan di Laboratorium Biologi , FKIP Universitas Muhammadiyah Surakarta.

\section{Pembuatan ekstrak etanol daun sirsak} Daun sirsak yang digunakan dalam penelitian ini diambil dari daerah Karanganyar. Kemudian dikeringkan menggunakan sinar matahari hingga kering dan disortasi kering dengan cara memisahkan pengotor atau benda asing yang masih tertinggal dalam simplisia. Selanjutnya daun yang telah kering diserbuk menggunakan blender. Ekstrak dibuat dengan cara maserasi menggunakan etanol 96\%.. Serbuk kering daun sirsak sebanyak 2001,75 g direndam dengan etanol $96 \%$ sebanyak $20000 \mathrm{~mL}$. Serbuk direndam sambil sekali-kali diaduk dan didiamkan sampai 24 jam. Maserat dipisahkan dan proses diulangi 2 kali dengan jenis dan jumlah pelarut yang sama. Semua maserat dikumpulkan dan diuapkan dengan vacum rotary evaporator. Hasil penguapan menggunakan vacum rotary evaporator dilanjutkan menggunakan penangas air untuk memperoleh ekstrak kental. Rendemen yang diperoleh ditimbang dan dicatat.

\section{Uji aktivitas antibakteri dengan metode dilusi padat}

\section{Preparasi media}

Media untuk uji aktivitas antibakteri: Media yang digunakan untuk uji aktivitas antibakteri ( $K$. penumoniae dan S.epidermidis) adalah media $\mathrm{MH}$. Pembuatan media dilakukan dengan cara melarutkan media dalam akuades sesuai dengan petunjuk dari tiap kemasan. Banyaknya media yang ditimbang untuk tiap liternya untuk media $\mathrm{MH}$ adalah $64 \mathrm{~g}$, sedangkan untuk media BHI $37 \mathrm{~g}$, untuk BHI double strength dibuat dengan penimbangan 2 kalinya, yaitu 74 g untuk 1 L. Jumlah media yang ditimbang disesuaikan dengan jumlah yang dibutuhkan. Kemudian media disterilkan pada suhu $121^{\circ} \mathrm{C}$ dengan tekanan 2 atm selama 15 menit.

\section{Pemeliharaan bakteri}

Biakan murni mikroba uji yaitu bakteri $K$. pneumonia dan S. epidermidis diambil satu ujung mata ose kemudian digoreskan pada media $\mathrm{MH}$, kemudian media padat yang telah digoresi dengan mikroba diinkubasi pada suhu $37^{\circ} \mathrm{C}$ selama 18-24 jam.

\section{Pembuatan suspensi mikroba uji}

Bakteri K.pneumoniae dan S.epidermidis masing-masing diambil satu ujung mata ose dari biakan induk dalam agar, kemudian disuspensikan dalam $1 \mathrm{~mL}$ media BHI steril, dan diinkubasi pada suhu $37^{\circ} \mathrm{C}$ selama 24 jam. Hasil biakan tersebut diambil $100 \mu \mathrm{L}$, kemudian disuspensikan ke dalam $1 \mathrm{~mL}$ media BHI steril, diinkubasi selama 3-4 jam pada suhu $37^{\circ} \mathrm{C}$. Kemudian konsentrasinya disamakan dengan standar Mc. Farland 108CFU/mL dengan cara mensuspensikannya dalam akuades steril hingga diperoleh kekeruhan yang sama. Untuk mendapatkan suspensi bakteri 106 $\mathrm{CFU} / \mathrm{mL}$, maka diambil sebanyak $50 \mu \mathrm{L}$ bakteri $108 \mathrm{CFU} / \mathrm{mL}$ dan disuspensikan dalam $5 \mathrm{~mL}$ media BHI double strength steril.

\section{Uji aktivitas antibakteri}

Pembuatan larutan stok 20\%: Delapan gram ekstrak kental daun sirsak dilarutkan dengan pelarut (DMSO 100\%) sampai $40 \mathrm{~mL}$. Konsentrasi ekstrak pada uji aktivitas antibakteri adalah 3,75\%, $3,5 \%, 3,25 \%, 3 \%$, dan $2,75 \%$ seperti 
Gambar 5. Larutan ekstrak dengan stok $20 \%$ diambil dengan beberapa seri volume kemudian ditambah akuades steril hingga $5 \mathrm{~mL}$. Setelah itu, larutan ekstrak diambil masing-masing $2 \mathrm{~mL}$ dalam tabung terpisah, ditambahkan media sebanyak $3 \mathrm{~mL}$ yang telah disterilkan sampai volume total masing-masing tabung sebanyak $5 \mathrm{~mL}$, kemudian dikocok hingga benar-benar homogen dan dipadatkan dalam posisi miring. Selanjutnya jika media yang telah dicampur ekstrak telah padat, suspensi mikroba 106 CFU/mL diteteskan sebanyak $25 \mu \mathrm{L}$, diratakan dengan ose steril, selanjutnya diinkubasi pada suhu $37^{\circ} \mathrm{C}$ selama $18-24$ jam kemudian diamati pertumbuhan bakterinya. Kadar terkecil yang dapat membunuh mikroba disebut Kadar Hambat Minimum (KHM). Kontrol untuk uji aktivitas antibakteri ekstrak etanol daun sirsak terhadap K. pneumoniae dan $\mathrm{S}$. epidermidis terdiri dari 3 macam: Kontrol media: Media Kontrol pertumbuhan: Media dan suspensi mikroba, Kontrol pelarut: Media dan suspensi mikroba serta pelarut DMSO $100 \%$.

\section{Kromatografi Lapis Tipis}

Ekstrak etanol daun

sirsak

dilarutkan dengan metanol. Larutan sampel ditotolkan pada plat KLT yaitu silika gel GF 254 sebagai fase diam yang telah diaktifkan sebelumnya pada suhu $100^{\circ} \mathrm{C}$ selama $1 \mathrm{jam}$, kemudian totolan tersebut dielusi dengan fase gerak heksan : etil asetat (7:3) v/v. Plat tersebut kemudian dikeringkan dan dianginanginkan kemudian diamati di bawah sinar tampak, UV $254 \mathrm{~nm}$, UV $366 \mathrm{~nm}$ dan dengan beberapa pereaksi semprot sitroborat, Liebermann-Burchard (LB), $\mathrm{KOH}$ etanolik $10 \%$, dan $\mathrm{FeCl}_{3}$ untuk mengidentifikasi golongan senyawa yang terdapat dalam ekstrak.

\section{Bioautografi}

Senyawa aktif yang memiliki aktivitas sebagai antibakteri dideteksi dengan metode bioautografi dengan cara dibuat konsentrasi 3\%. Kemudian ditotolkan di plat KLT sebanyak $2 \mu \mathrm{L}$ dan dielusi dengan fase gerak heksan : etil asetat (7:3) v/v. setelah itu, plat KLT diletakkan pada permukaan media $\mathrm{MH}$ dalam petri yang telah diinokulasi dengan bakteri K. pneumonia dan S.epidermidis selama 20 menit. Setelah itu, diinkubasi selam18-24 jam pada suhu $37^{\circ} \mathrm{C}$. bila bercak-bercak pada plat KLT tersebut memiliki aktivitas antibakteri maka dengan adanya difusi golongan senyawa aktif akan terbentuk zona jernih yang merupakan zona hambatan.

\section{HASIL DAN PEMBAHASAN}

Hasil ekstraksi: Daun sirsak yang digunakan diambil dari daerah Jumapolo, Karanganyar. Hasil determinasi daun memastikan bahwa daun yang digunakan berasal dari tanaman sirsak (Annona muricata L.). Daun sirsak dibuat menjadi simplisia kering kemudian diserbuk yang bertujuan untuk memperluas permukaan simplisia ketika kontak dengan cairan penyari. Selanjutnya serbuk simplisia dimaserasi dengan pelarut etanol $96 \%$. Hasil maserasi simplisia sebanyak 2001,75 gram menghasilkan 598,66 gram ekstrak kering etanol. Ekstrak kering difraksinasi dengan menggunakan $\mathrm{KCV}$, sehingga terbentuk fraksi non polar, semi polar dan polar.

Hasil Uji Aktivitas Antibakteri: Metode yang digunakan dalam uji aktivitas antibakteri adalah dilusi padat. Metode dilusi padat mempunyai keunggulan dibandingkan dengan metode dilusi cair, yaitu satu konsentrasi dapat digunakan untuk beberapa mikroba uji. Parameter yang digunakan dalam uji aktivitas antibakteri menggunakan metode dilusi padat adalah KHM (Kadar 
Hambat Minimum). Nilai KHM adalah konsentrasi terkecil dari ekstrak etanol daun sirsak yang dapat membunuh mikroba.

Validitas uji antibakteri ini diperkuat dengan penggunaan 3 kontrol. Kontrol media (K1) bertujuan untuk mengetahui sterilitas media yang digunakan. Kontrol pertumbuhan (K2) bertujuan untuk mengetahui bakteri atau jamur dapat tumbuh baik pada media atau tidak. Kontrol pelarut (K3) bertujuan untuk mengetahui aktivitas antibakteri DMSO yang digunakan sebagai pelarut DMSO 100\% sebagai pelarut digunakan untuk membantu melarutkan ekstrak, sehingga ekstrak dapat terdispersii merata. Uji aktivitas antibakteri ekstrak etanol daun sirsak dilakukan terhadap 5 seri konsentrasi ekstrak.

Konsentrasi ekstrak etanol daun sirsak yang diuji adalah $2,5 \% ; 3 \% ; 3,5 \%$; $4 \%$; dan 4,5\%. Hasil uji aktivitas antibakteri ekstrak etanol daun sirsak terhadap $K$. pneumonia dan S. epidermidis memiliki nilai KHM berturut- turut sebesar 2,5; 3; 3,5\%. Fraksi Non polar memiliki nilai KHM sebesar 4; 4,5; 4,5\%; sedangkan fraksi Semi polar mempunyai KHM berturut-turut 2,5; 3; 3,5\%; selanjutnya fraksi Polar memiliki KHM sebesar 2,5; 2,5 dan 3\% (Tabel 1).

Aktivitas antibakteri terhadap bakteri K. pneumoniae dan S. epidermidis pada penelitian ini lebih rendah dibanding penelitian-penelitian sebelumnya. Prachi et al. (2010) melaporkan ekstrak metanol daun sirsak asal India pada konsentrasi $0,9 \%$ memiliki aktivitas antibakteri terhadap K. pneumonia NCIM No. 2719 dengan nilai KHM 17 mm menggunakan metode agar cup. Aktivitas antibakteri fraksi polar ekstrak etanol daun sirsak lebih tinggi dibandingkan ekstrak etanolnya sehingga kemungkinan senyawa yang bersifat antibakteri adalah senyawa polar (Kosworo, 2012). Saputro (2012) dan Septianingrum (2012) melaporkan fraksi semipolar dan nonpolar ekstrak etanol daun sirsak efektif membunuh $K$. pneumoniae dan $S$. epidermidis pada konsentrasi berturutturut $3,5 \%$ dan $4 \%$. Hasil uji aktivitas antibakteri menunjukkan bahwa potensi antibakteri ekstrak etanol daun sirsak adalah $K$. pneumoniae > S. epidermidis. Hal tersebut kemungkinan dapat disebabkan oleh kemampuan $S$. epidermidis memproduksi kapsul atau lendir dalam pembentukan biofilm sehingga terlindung dari serangan antibakteri (Mack et. al., 2006).

Tabel 1. Hasil UJi Antibakteri Ekstrak Etanol, Fraksi Non Polar, Semi Polar dan Polar Daun Sirsak

\begin{tabular}{lllllllll}
\hline \multirow{2}{*}{$\begin{array}{l}\text { Konsentrasi } \\
(\% \text { b/v) }\end{array}$} & \multicolumn{3}{l}{ Klebsiella pneumoniae } & \multicolumn{5}{c}{ Staphylococcus epidermidis } \\
\cline { 2 - 9 } & Ekstrak & $\begin{array}{l}\text { Non } \\
\text { polar }\end{array}$ & $\begin{array}{l}\text { Semi } \\
\text { polar }\end{array}$ & Polar & Ekstrak & $\begin{array}{l}\text { Non } \\
\text { polar }\end{array}$ & $\begin{array}{l}\text { Semi } \\
\text { polar }\end{array}$ & Polar \\
\hline 2,5 & + & - & + & + & + & - & + & + \\
3 & + & - & + & - & + & - & + & + \\
4 & -5 & - & - & - & + & - & + & - \\
4,5 & - & + & - & - & - & - & - & - \\
K1 & - & + & - & - & - & + & - & - \\
K2 & - & - & - & - & - & - & - & - \\
K3 & + & + & + & + & + & + & + & + \\
\hline
\end{tabular}

Keterangan :

(+) : tidak terhambat pertumbuhan bakteri

(-) : : terdapat hambatan pertumbuhan mikroba

K2 : kontrol pertumbuhan

K1 : kontrol media

K3 : kontrol pelarut DMSO 100\% 
Hasil Uji Kromatografi Lapis Tipis: Identifikasi golongan senyawa dalam ekstrak dilakukan dengan menggunakan kromatografi lapis tipis. Fase gerak yang digunakan adalah heksan:etil asetat $(7: 3)$ $\mathrm{v} / \mathrm{v}$. Bercak yang mempunyai harga Rf 0,62 dengan reagen semprot sitroborat pengamatan pada UV $366 \mathrm{~nm}$ tidak berfluoresensi kuning sehinggamungkin bukan merupakan senyawa flavonoid. Bercak dengan Rf 0,80 merupakan senyawa saponin tipe triterpenoid karena pada UV $366 \mathrm{~nm}$ setelah disemprot pereaksi Liebermann- Burchard bercak berfluoresensi merah. Bercak dengan Rf 0,85 merupakan senyawa steroid karena pada UV $366 \mathrm{~nm}$ setelah disemprot Liebermann- Burchard bercak berfluoresensi biru. Bercak dengan nilai Rf 0,31 dan 0,62 merupakan antrakinon karena pada sinar tampak setelah disemprot $\mathrm{KOH}$ etanolik $10 \%$ bercak berwarna kuning. Bercak dengan nilai Rf 0,$38 ; 0,50 ; 0,65$ dan 0,77 merupakan polifenol karena pada sinar tampak setelah disemprot $\mathrm{FeCl}_{3}$ bercak berwarna abu-abu.
Hasil Uji Bioautografi : Bila dilihat pada media $\mathrm{MH}$, pertumbuhan K.pneumoniae tampak jernih pada $\mathrm{Rf}$ 0,$38 ; 0,50 ; 0,62 ;$ dan 0,80 . Berdasarkan hasil KLT, bercak pada Rf 0,80 merupakan senyawa golongan saponin yaitu triterpenoid saponin yang mempunyai aktivitas antibakteri dengan cara mengubah permeabilitas membran terkait dengan perubahan dalam homeostatis antara kompartemen intraseluler dan ekstraseluler (Melzig et al., 2001). Bercak pada Rf 0,50 dan 0,38 merupakan senyawa polifenol. Bercak pada $\operatorname{Rf} 0,62$ adalah senyawa golongan antrakinon yaitu antron dan antranol.

Hasil bioautografi pada media $\mathrm{MH}$ yang diinokulasi dengan Staphylococcus epidermidis didapatkan zona jernih pada Rf 0,31 ; 0,$38 ; 0,50 ;$ dan 0,65. Diameter zona jernih yang berada pada $\operatorname{Rf} 0,38 ; 0,50$; dan 0,65 merupakan senyawa golongan polifenol. Sedangkan bercak pada $\mathrm{Rf}$ 0,31 merupakan senyawa golongan antrakinon.

Tabel 2. Hasil Analisis KLT Ekstrak Etanol Daun Sirsak dengan Fase Gerak Heksan:Etil Asetat (7:3)

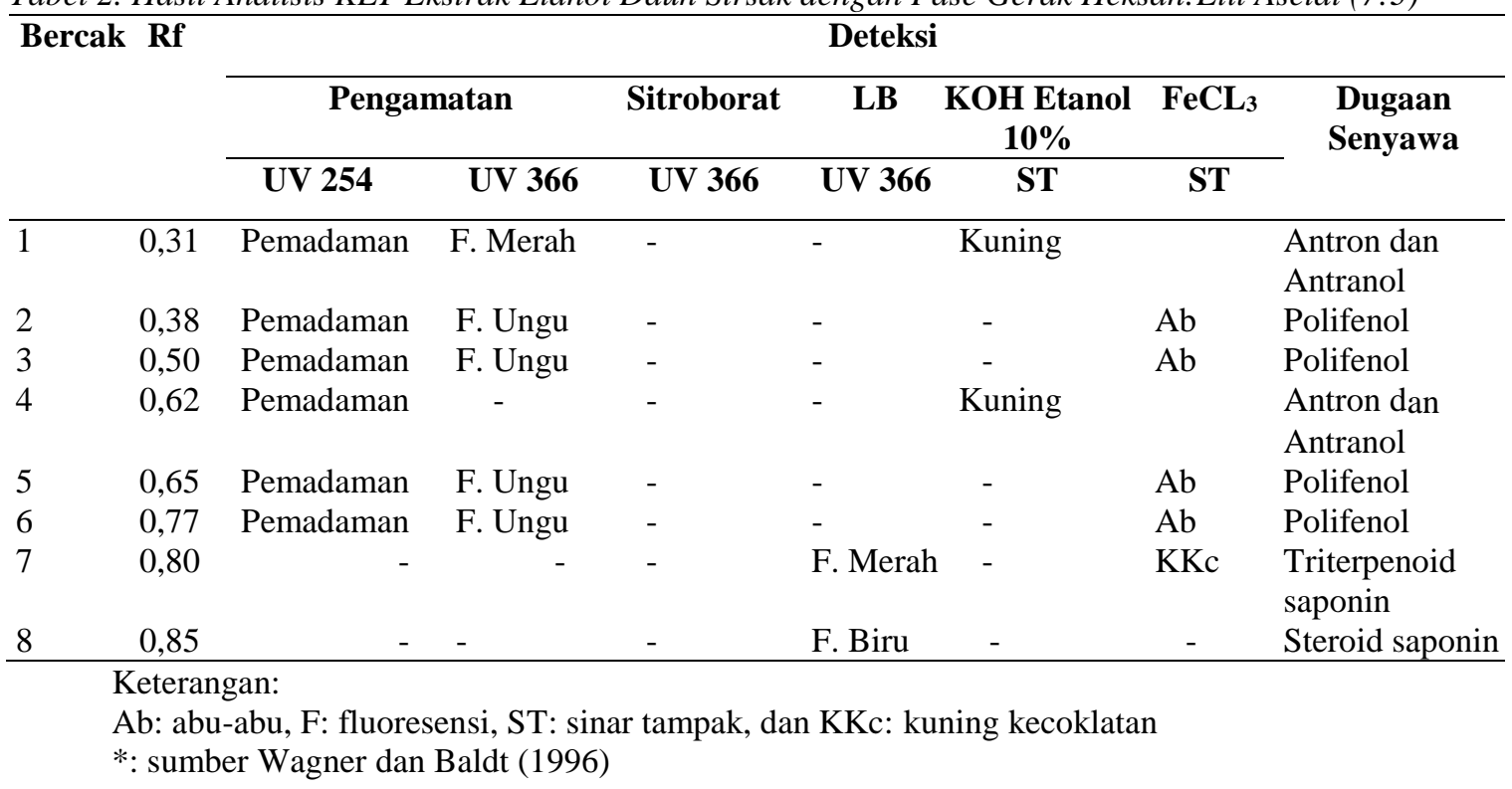




\section{KESIMPULAN}

Ekstrak etanol, fraksi non polar, semi polar dan polar daun sirsak (Annona muricata L.) mempunyai aktivitas antibakteri terhadap Klebsiella pneumoniae dan Staphylococcus epidermidis dengan Kadar Bunuh Minimum (KBM) berturut-turut sebesar $2,5 \% 3 \% ; 3,5 \% ; 4 \%$ dan $4,5 \%$. Hasil Kromatografi Lapis Tipis menunjukkan bahwa ekstrak etanol daun sirsak (Annona muricata L.) mengandung senyawa steroid saponin, triterpenoid saponin, polifenol, antron, dan antranol. Seyawa golongan saponin, polifenol, dan antrakinon memiliki aktivitas antibakteri terhadap Klebsiella pneumonia. Sedangkan, golongan senyawa yang memiliki aktivitas antibakteri terhadap Staphylococcus epidermidis yaitu golongan antrakinon dan polifenol..

\section{UCAPAN TERIMAKASIH}

Disampaikan kepada Dekan Fakultas Farmasi, dan Ketua LPPM UMS yang telah mensupport penelitian ini.

\section{DAFTAR PUSTAKA}

[1]. Akiyama, H., Fujji, K., Yamasaki, O., Oono, T., Iwatsuki, K., 2001, Antibacterial Action of Several Tannins Against Staphylococcus aureus, Journal of Antimicrobial Chemotherapy, 48, 4, 487-491.

[2]. Batubara dan Priyanto, L., 2008, Farmakologi Dasar, Depok, Leskonfi.

[3]. Danan, C. R.,2011,

Klebsiella pneumoniae, (online), (http://mikrobia.files.wordpress.com/2008/0 5/cornelius-danan-r-078114100.pdf, diakses tanggal 26 Februari 2011).

[4]. Fitzpatrick, P., Humphreys, H., and O'Gara, J. P., 2005, The Genetics of Staphylococcal Biofilm Formation-will a Greater Understanding of Pathogenesis Lead to Better Management of Device-Related Infection?, Clinical Microbiology and Infection, 11, 967-973.
[5]. Hertiani T., Palupi, I. S., Sanliferianti, Nurwindasari, H. D., 2003, Uji Potensi Antibakteri terhadap S. aureus, E. coli, Shigella dysentriae, dan Candida albicans dari Beberapa Tanaman Obat Tradisional untuk Penyakit Infeksi, Pharmacon, 4, 2.

[6]. Isaacs, D. dan Australasian Study for Neonatal Infections, 2003, A Ten Year, Multicenter Study of Coagulase Negative Staphylococcal Infections in Australasian Neonatal Units, Arch Dis Child Fetal Neonatal, 2, 89-93.

[7]. Kosworo, 2012, Aktivitas Antibakteri dan Bioautografi Fraksi Polar Ekstrak Etanol Daun Sirsak (Annona muricata L.) terhadap Klebsiella pneumoniae dan Staphylococcus epidermidis, Skripsi, Surakarta, Fakultas Farmasi, Universitas Muhammadiyah Surakarta.

[8]. Mack, D., Davies, A., Harris, L., Rohde, H., Horstkotte, M., and Knobloch, J., 2006, Microbial Interactions in Staphylococcus epidermidis Biofilm, Analytical and Bioanalytical Chemisty, 387, 399-400.

[9]. Melzig, M. F., Bader, G., and Loose, R., 2001, Investigations of the Mechanism of Membrane Activity of Selected Triterpenoid Saponins, Thieme Journal, Planta Med, 67, 1, 43-48.

[10]. Podschun, R., and Ullmann, U., 1998, Klebsiella spp. as Nosocomial Pathogens, Epidemiology, Taxonomy, Typing Methods, and Pathogenicity Factors, American Society for Microbiology, 11, 4, 589-603.

[11]. Prachi, P., Saraswathy., Vora., and Savai., 2010, In Vitro Antimicrobial Activity and Phytochemical Analysis of The Leaves of Annona muricata, International Journal of Pharma Research and Development, 2, 5, 16.

[12]. Santosa, C. M., Hertiani, T., 2005, Kandungan Senyawa Kimia dan Efek Ekstrak Air Daun Bangun-Bangun (Coleus amboinicus L.) Pada Aktivitas Fagositosis Netrofil Tikus Putih (Rattus norvegicus), Majalah Farmasi Indonesia, 16, 3, 141-148.

[13]. Saputro, H. P. W ., 2012, Aktivitas Antibakteri dan Bioautografi Fraksi semipolar Ekstrak Etanol Daun Sirsak (Annona muricata L.) terhadap Klebsiella pneumoniae dan Staphylococcus epidermidis, Skripsi, Surakarta, Fakultas Farmasi, Universitas Muhammadiyah Surakarta. 
Aktivitas antibakteri dan bioautografi ekstrak etanol, fraksi non polar, semipolar serta polar daun sirsak (Annona muricata l.) terhadap klebsiella pneumoniae dan staphylococcus epidermidis

[14]. Septianingrum, R. U. D., 2012, Aktivitas Antibakteri dan Bioautografi Fraksi nonpolar Ekstrak Etanol Daun Sirsak (Annona muricata L.) terhadap Klebsiella pneumoniae dan Staphylococcus epidermidis, Skripsi, Surakarta, Fakultas Farmasi, Universitas Muhammadiyah Surakarta.

[15]. Taylor, L., 2002, Herbal Secrets of the Raintforest, Second Ed., Sage Press, Inc.

[16]. Vieira, G. H. E., Mourao, J. A., Angelo, A. M. Costa., R. A., and Vieira R. H. S. E., 2010, Antibacterial Effect (in vitro) of Moringa oleifera and Annona muricata Againts Gram Positive and Gram Negative Bacteria, Revista do Instituto de Medicina Tropical de Sao Paulo, 52, 3, 129-132.
[17]. Wagner, H., and Bladt, S., 1996, Plant Drug Analysis: A Thin Layer Chromatography Atlas, Second Ed., 350.

[18]. Westh, H., Zinn, C. S., Rosdahl, V. T., 2004, An International Multicenter Study of Antimicrobial Consumption and Resistance in Staphylococcus aureus Isolates From 15 Hospitals in 14 Countries, Microb Drug Resist, 10, 169-176. 